\title{
Practice and Exploration of Experiential Teaching Method in Innovative Entrepreneurship Education
}

\author{
YiXian Zhang \\ Business Management Department. Neusoft Institute Guangdong \\ Foshan, China
}

\begin{abstract}
In order to improve the teaching effect of innovative entrepreneurship course in applied undergraduate colleges, the basic course of innovation and entrepreneurship in Guangdong Neusoft Institute is studied from the aspects of teaching idea, teaching content, teaching method and teaching arrangement. This paper explores the practice of practice-oriented experiential teaching method, introduces the relevant experience in the application of this method in the two courses of innovation and entrepreneurship simulation, and analyzes the effect of implementing experiential teaching method through student evaluation. Finally, the safeguard measures to implement this method are put forward.
\end{abstract}

Keywords-Applied undergraduate college; Innovation and entrepreneurship; Experiential teaching method; Flipping course; Simulation teaching method

\section{INTRODUCTION}

Since the publication of the No.1 document of Guangdong Neusoft Institute students Innovation and Entrepreneurship leading Plan in 2015, the innovation and entrepreneurship reform has entered the fast track, and a more perfect multi-level innovation and entrepreneurship education system has been built, which includes professional and experienced teachers from inside and outside the university, and has formed a positive entrepreneurial atmosphere. Summing up the achievements and experiences in running schools over the past few years will contribute to a better plan of future work. And provide advices to build a high level of entrepreneurial technology universities with characteristics [1].

As one of the driving forces of China economic growth, the policy of "mass entrepreneurship and innovation" has become more and more popular. Entrepreneurship management education has been paid more and more attention by the government and different colleges and universities. Entrepreneurship management teaching is a new subject, and effective classroom teaching methods are still in the exploratory stage [2].

\section{BASE SITUATION}

\section{A. The basic composition of the curriculum system of innovation and entrepreneurship}

For many years, Neusoft Institute has constructed an all-process and progressive platform of innovation and entrepreneurship, consisting of innovative entrepreneurship courses, innovation and entrepreneurship center SOVO, start-up 18MALL incubator, Neusoft South China IT start-up park. The course of innovation and entrepreneurship mainly

This paper is funded by Neusoft Institute Guangdong of Education Reform in 2018, "Research on the Construction of course system of Innovation and Entrepreneurship based on the whole process of Talent training" (Project No. 2018014) includes the compulsory course "Foundation of Innovation and Entrepreneurship" for all students, the compulsory course "Simulation of Innovation and Entrepreneurship", the elective course "practice of Innovation and Entrepreneurship" and the courses of innovation in various specialties. SOVO and 18MALL are virtual entrepreneurial teams organized by college students under the guidance of teachers. Neusoft South China IT Start-up Park is a startup park for college students and social entrepreneurs. Theoretical study, project practice and company operation constitute the curriculum the main system of innovation and entrepreneurship.

\section{B. Problems in the course of innovation and entrepreneurship}

Although innovative entrepreneurship education has made some achievements, but there are also problems that can not be ignored. Some problems were identified in a May 2017 survey of undergraduates in grade 2015. First of all, students do not know enough about innovation and entrepreneurship. The question "do you think entrepreneurial ability is important to personal development?" $21.51 \%$ of the answer is "average". To the question "what do you think is the relationship between the cultivation of innovative entrepreneurship and the major you are studying," $30.43 \%$ of the students answered "No relationship".

Secondly, only $64.48 \%$ of the students felt that their ability to innovate had "improved significantly" or "improved to some extent". Only $54.98 \%$ of the students felt that their entrepreneurial ability had "improved significantly" or "improved to some extent". For the two public compulsory courses of innovation and entrepreneurship, 30\% of the students said that "both the teaching content and the teaching methods need to be strengthened."

Finally, the integration of classroom education and innovation and entrepreneurship is not enough. Students believe that classroom education plays a secondary role in the cultivation of innovative entrepreneurial ability.

From the teaching practice of Guangdong Neusoft Institute, there are still some problems in teaching methods, such as paying attention to theory and despising practice. It is very urgent to explore new teaching methods of innovative and entrepreneurial courses. 


\section{INNOVATIVE ENTREPRENEURSHIP CURRICULUM AND EXPERIENTIAL TEACHING METHOD}

Innovative entrepreneurship education has independent and unique teaching content and talent training goals. Innovation is the soul, entrepreneurship is the carrier. Innovation and entrepreneurship is a kind of practice behavior. Innovative entrepreneurship education unifies "knowledge and action" and implements "teaching, learning, and doing in one." It is a student-centered teaching model of active learning, and a learning process centered on subjects, projects and tasks. It is a systematic learning process that combines goal and operation. Therefore, it has its own unique educational idea, the knowledge system, the ability structure and the value orientation [3].

From the curriculum system and teaching content combination form, because of different regions, different teaching resources, different levels of categories and training objectives, so the formal content can be varied. It is impossible to simplify one. But from the point of view of system structure and system content configuration, it must include the cultivation of innovative entrepreneurial consciousness and spirit, the imparting of relevant knowledge, the training of practical skills [3].

The so-called "experiential teaching method" means that according to the students cognitive process and characteristics, "experience" is highlighted in the study preparation stage, the classroom teaching stage, the after-class continuation stage and the evaluation and analysis stage, so that students can take the initiative to participate and explore actively. Active thinking, active operation, automatic activity is characteristic [4]. The so-called "simulation teaching method" is to use software or tools to enable participants to play a certain role in an environment close to reality, and interact with the people or things involved, in order to achieve the desired learning purpose. Both experiential teaching and simulated teaching are learner-centered. In a specific simulation environment, the teaching process is carried out through projects, activities and tasks. The "simulated teaching method" emphasizes on describing the construction of teaching environment needs the means of software simulation. In essence, "simulated teaching" also belongs to the category of "experiential teaching method".

The main characteristics of experiential teaching of entrepreneurship curriculum include subjective experience, cooperative interaction, teaching in fun, consistency of learning and use, and environmental support [4].

The experiential teaching method can not only trigger the students' active consciousness and learning spirit, but also lead to the participation of other psychological factors, and have a direct impact on the entrepreneurial personality and emotional factors in entrepreneurial literacy. For example, planning ability, organization ability, leadership ability, management ability, team spirit and so on, are easier to develop in project groups and specific practice activities.

\section{APPLICATION OF EXPERIENTIAL TEACHING METHOD}

\section{A. Application of experiential Teaching method based on practice}

The course orientation of "Foundation of Innovation and Entrepreneurship" in Guangdong Neusoft Institute is mainly to let students understand the inherent law of the process of entrepreneurial activity and the independence of the entrepreneurial activity itself, to understand the problems often encountered in the process of starting a business and the characteristics of the initial enterprise.

Specifically, we should cultivate students' awareness of initiative and innovation, strengthen entrepreneurship, cultivate and exercise entrepreneurial skills such as opportunity identification, innovation, resource integration, team building, knowledge integration, etc. To guide students to work with entrepreneurial thinking, think and learn like entrepreneurs, cultivate and strengthen the ability of creative analysis and problem-solving, and enhance the ability of innovation [5].

The course was developed in the form of "flip classroom". Students learn the "Foundation of Innovation and Entrepreneurship" by Zhang Yuli of Nankai University before the opening of the course, and "Foundation of Entrepreneurship" by Li Jiahua of China Youth Institute of political Science, etc. In the classroom, teachers mainly focus on the knowledge point explanation, group discussion, case study, project report and so on. In the study preparation stage, the students study the online curriculum resources according to the topic before the class, or divide into groups to implement the survey projects, or study the innovative entrepreneurial cases in groups; In the course teaching stage, it is mainly to share the project implementation, research report or case analysis report of each group according to the theme, and the teacher makes comments. Tasks, voting, brainstorming, testing, evaluation and other activities in the course are managed through the teaching management software "Blue Moo Cloud Class" APP; After class, students reflect on the contents and activities of classroom learning and complete or perfect group report.

The current extracurricular projects include investigating the entrepreneurs around you, analyzing what business opportunities exist in the university town, visiting the enterprises around you, seeing who sells more, marketing planning practical competitions, writing business plans and so on. Through the "flip classroom" arrangement, students have mastered the basic knowledge before class, and then completed the relevant projects after class. Through case analysis, project achievement report, investigation report display in class to consolidate knowledge and stimulate thinking. Cultivate innovative entrepreneurial spirit and improve innovative entrepreneurial skills. 


\section{B. Application of software simulation teaching method}

In the "Innovation and Entrepreneurship Simulation" course, "Financial Empire II" was chosen as a teaching software tool to simulate entrepreneurial decision-making. After students formed a team and selected industries, each participant started a business enterprise. And carry out a series of decisions and practices in team competition. The orientation of the course is: when the students have the basic knowledge of innovation and entrepreneurship, through the simulation software platform, let the students carry out 10-30 years of entrepreneurial simulation practice, students by looking for opportunities, starting a business, making decisions, managing a simulation company, Evaluate company performance to help students develop and improve business judgment.

Under the guidance of the teacher, the students decide the industry, products and services according to the initial intention of starting a business, in which all events and environment will change as economic decisions are made. The special point of entrepreneurial simulation practice is that they enable students to participate in every stage from brand building, scientific research management, product production, supply, sales, stock issuance and operation of financial market, bank loan and so on. By taking a proactive response to competitors' actions and choosing among a variety of options for action, students can discern the signals of change in the industry, accurately find market opportunities, evaluate the competitive position of the company and the threats it faces. Find a balance between higher profits now and higher profits in the future, and evaluate the long-term consequences of short-term decisions.

In the teaching arrangement, first of all, the teacher introduces the teaching task briefly, the students teach themselves the relevant part of the textbook before class, refer to the relevant contents of the textbook in the classroom, operate the primary mode of the software, the teacher gives the operation instruction; Then, students should teach themselves the basic knowledge of four major industries before class, teachers explain the main points of basic operation in class, students run retail, manufacturing, agriculture, finance four major industries; Finally, the team members compete in the group and calculate the scores according to each personal rank. Each industry is a complete business process simulation, including opportunity identification, business model design, team building, resource integration and so on.

\section{Effect evaluation after implementing experiential teaching method}

After adjusting the teaching methods of "Foundation of Innovation and Entrepreneurship" and "Simulation of Innovation and Entrepreneurship", the teaching effect has been greatly improved.

According to the October 2018 survey, "how do you feel about your ability to innovate have changed through college?" The percentage of "significantly improved" or "somewhat improved" responses rose from 64.48\% in October 2017 to $78.05 \%$ in October 2018. In the answer to "how do you feel your entrepreneurial skills have changed through college studies," the proportion of "significantly improved" or "somewhat improved" rose to 68.91 percent from 54.98 percent in October 2017. According to the answer of
"Evaluation of the Teaching effect of the course of Innovation and Entrepreneurship", the proportion of "very good" or "relatively good" has risen from 35.3\% in October 2017 to $64.88 \%$ in October 2018.

\section{THE STRATEGY OF IMPLEMENTING EXPERIENTIAL TEACHING METHOD}

\section{A. Constructing the system of online and offline courses}

The government coordinates, colleges and universities actively cooperate, strengthen international exchanges, rely on existing resources such as MOOC (large-scale online open courses), video open courses, high-quality courses in colleges and universities to build cross-disciplinary, cross-regional and low-cost resources, Comprehensive Innovation and Entrepreneurship online Curriculum system [6]. We should construct an off-line curriculum system of innovation and entrepreneurship, such as compiling excellent teaching materials, compiling excellent cases, conceiving practical projects, establishing high-quality practice bases, building innovative entrepreneurial platforms, conducting innovative entrepreneurship competitions, and organizing lectures on entrepreneurs, Introduce government services, etc.

\section{B. Improving the professional level and teaching level of teachers}

It is essential to improve the professional level of teachers. In addition to being familiar with relevant theoretical knowledge, teachers of innovative entrepreneurship courses also need to increase their practical operational experience. Schools can encourage teachers to set up enterprises, take up short-term career training in enterprises, participate in enterprise projects, learn to improve their practical ability.

Attention should be paid to the training of teaching software tools. Many effective software tools are a powerful weapon to promote reform in the process of implementing "flip classroom" and "experiential teaching method".

\section{Vigorously promote the reform of school management system and construct the institutional environment}

In the practice of promoting teaching methods such as "flipping classroom", "experiential teaching method" and "simulated teaching method", the demand for teaching resources has increased, such as the need for more flipping classrooms, simulation teaching software, MOOC and high-quality open curriculum resources. Training base, creators space, all kinds of innovative entrepreneurial competition and so on; Secondly, teachers need to strengthen the ability to use software tools, teaching skills, professional practical skills, and so on; Thirdly, schools need a wider range of external educational resources, such as outside experts, entrepreneurs, managers, and government departments. This requires schools to attach great importance to teaching reform, better improve the hardware, software, human resources and other conditions required for teaching reform, and finally promote the improvement of teaching level and teaching effect. 


\section{CONCLUSION}

Experiential and simulated teaching methods emphasize learning through doing, and innovative entrepreneurship courses need to combine knowledge and theory with practice. The practice proves that the experiential teaching method is suitable for the characteristics of the innovative and entrepreneurial courses, and the experiential teaching method is better than the simple teaching method. At the same time, the implementation of experiential teaching method requires the school to have better hardware, software and management level.

\section{REFERENCES}

[1] Zhang Yixian. Exploration and practice of Applied undergraduate Innovation and Entrepreneurship Education system [J]. Management Watch, 2016 (13).

[2] Su Shibin. Case study on Innovation of Entrepreneurial Management course [J]. Experimental Technology and Management, 2018 (06).

[3] Cao Shengli. Innovative Entrepreneurship Education calls for simulated Teaching and experiential courses $[\mathrm{J}]$. Experimental Technology and Management, 2009 (08).

[4] Han Meigui, Liu Zhiyuan. Exploration of implementing experiential Teaching in the course of Entrepreneurship Education [J]. Vocational and Technical Education in China, 2007 (06).

[5] Zhang Yuli, Chen Hansong, Xue Zhihong. The Foundation of Entrepreneurship [M]. Beijing: mechanical Industry Press, 2013.

[6] He Enqi, Li Hua, Ma Yurong. Exploration of online and Off-line Teaching combination Model of innovative Entrepreneurship course [J]. Academic Theory, 2018 (08). 